\title{
ПОНЯТІЙНО-ПРАВОВЕ МИСЛЕННЯ В ДАВНІЙ ГРЕЦІЇ: ВІД МІФУ ДО ЕПІСТЕМИ
}

\author{
Кучеренко Д. С., Гамбург Л. С.
}

\section{ВСТУП}

Виникнення права та ранні етапи становлення правової думки можна простежити 3 певним ступенем достовірності лише 3 моменту, коли 3'являються письмові джерела. Перші письмові джерела, в яких розкривається традиція європейського світосприйняття та світорозуміння, 3'явилися в Давній Греції. Метою цього дослідження є розкриття на основі аналізу текстів міфопоетичних, філософських і донаукових творів, які збереглися до нашого часу, зародження та становлення понятійноправового мислення; з'ясування його місця i ролі в давньогрецькому понятійному мисленні.

На початку давньогрецької історії та культури, коли ще діяли родові принципи в господарському та культурному житті, панівною формою світогляду була міфологія (грец. mythologia, від mythos - «мовлення, слово; оповідь, розповідь» та logos - «слово, вчення»). Вона постала результатом нагальної духовної потреби пояснити світ і розібратися в явищах природи. Ще не озброєна філософією та наукою допитлива думка родової людини поривалася до осягнення регулятивних сил буття природи та людей. 3 поширенням магічного типу пізнання людина переносила психічні відчуття та сприйняття, що виникали в ii психіці, формуючись під впливом навколишнього середовища і власного внутрішнього стану, безпосередньо на об'єкт, розглядала їх як свої властивості (антропоморфізм). Цей процес відбувався шляхом персоніфікування, уособлення в образах богів, перед якими людина відчувала подив, безсилля, необхідність схилення. Суть міфологічного феномена влучно виявив Г. Гегель: «Все содержание, приписываемое богам, должно оказаться вместе с тем собственной внутренней сущностью индивидов, так что, с одной стороны, господствующие силы представляются индивидуализированными сами по себе, а с другой стороны, это внешнее для человека начало оказывается имманентным его духу и характеру» ${ }^{1}$. Міфологія являла собою спробу пояснення явищ природи та життя людей, взаємовідносин земного та космічного початків образно-художнім способом. Міфи установлювали

\footnotetext{
1 Николаева Л., Поломошнов А. Философия : учебник. Ч. 1. История мировой философии. Персиановский : Донской ГАУ, 2017. С. 10.
} 
особисто та соціально прийняту в суспільстві значущу систему цінностей, що підтримувала і санкціонувала відповідні норми поведінки, взаємини між людьми та їхнє ставлення до світу. Зміст міфу уявлявся родовій людині цілковито реальним, і навіть у вищому смислі реальним, і був не формою реального знання, а предметом віри. Філософське питання про походження світу першим поставив Гесіод (кінець VIII - початок VII ст. до н. е.) у «Теогонії». Він виклав міфи як єдине ціле, описав родовід і перипетії в сонмі олімпійських богів. Богиня справедливості Діке та Необхідність $є$ початком усякого земного народження та злиття - та, яка надсилає жінку сховатися із чоловіком i, навпаки, чоловіка із жінкою. Земні жінки народжують героїв, про яких розповідають «ліада» й «Одіссея» Гомера (VIII ст. до н. е.). Оформлення міфологічного типу пізнання дозволило людині здійснити вихід за межі безпосередньо-чуттєвої, наочної дійсності. Давньогрецька міфологія несла на собі відбиток демократичної ментальності, вона була взірцем високохудожньої авторської творчості. Специфічною ऑiі особливістю були спроби причинно-наслідкового пояснення подій, а також наявність узагальнюючих сентенцій, художніх метафор, які можна розглядати як прообрази філософсько-наукових понять. Поступово образ мислення почав наповнюватися раціональним змістом i відповідними формами узагальнюючого й аналітичного мислення, відбувався перехід від міфу до логосу. Усе це наближало міфологічну традицію до натурфілософської стадії свідомості та пізнання, що найяскравіше проявилася в античній філософії.

\section{1. Від міфу до логосу}

Антична філософія постала 3 міфології та являє собою форму донаукового знання, у надрах якої поступово оформлюється натурфілософський тип пізнання (у філософії Греції класичного періоду). Це перша стадія розвитку понятійної здатності свідомості, що з'являється в результаті відокремлення розумової діяльності від безпосередньо практичної. У Давній Греції зародження філософії означало кінець міфологічного мислення та початок становлення раціонального знання. На початку VI ст. до н. е. мілетські мислителі Фалес (прибл. 624 р. до н. е. 548 р. до н. е.), Анаксімандр (610-547/540 рр. до н. е.) та Анаксімен (585/560-525/502 рр. до н. е.) започаткували новий тип роздумів про природу, зробили останню предметом систематичного неупередженого дослідження та запропонували споглядальну цілісну картину як теорію (грец. theoria - «дивитися, споглядати, спостерігати»). Уже у Фалеса Мілетського вперше в історії людського мислення постає проблема початків явищ матеріальної дійсності з погляду ії понятійного осмислення. 
Зробивши стрибок від чуттєвого до понятійного, Фалес не ігнорує подальше визначення цього понятійного (загального), а порушуэ питання про рух думки від загального до окремого.

У поемі Парменіда Елейського (540-480 рр. до н. е.) «Про природу» яскраво зображено стадію переходу від міфу до логосу. Парменід вперше здійснив спробу раціонального осмислення буття в аксіоматично побудованій системі, увівши до тексту поеми термін «буття» (грец. to einai). У вступній частині поеми описується подорож юнака-героя до палацу Істини. Парменід принципово розрізняє гадку «доксу» (грец. doxa) як позірність та достеменне знання сутності, істину «алетейа» (грец. aletheia). Вступ описує ні що інше, як поріг, на якому відбувається висування зы світу докси та входження до палацу Істини, тобто перехід й ініціація. Перехід героя в стан «мужа, який пізнав» набуває очевидного смислу ініціації мислення. Вступна частина поеми - це шлях підіймання до істини, тоды як шлях гадки - шлях спускання до докси. Цим пояснюється та послідовність частин, про яку говорить богиня-Істина, що їй все одно, звідки починати. Якщо вступ - це шлях сходження на гору, то природним продовженням руху думки має стати підкорення вершини та повернення назад - до світу буденної гадки, до світу, протоптаного людськими стежками. А сам шлях до істини лежить, за словами Парменіда, поза людською стежиною: «Ведь не злой рок руководил тобою по этой дороге, ибо далеко вне людской тропы пролегает она, но право и справедливость» ${ }^{2}$. Ця позамежність характеризує подію думки як подію за межами докси, отже, й норми. Мисленнсвий зачин, що вступає в суперечність із доксою, породжує парадокси, що грецькою буквально означає «за межами докси». Такі парадокси Парменід наводить у центральній частині поеми: «На этом пути находится немало признаков, говорящих, что бытие безначально, неуничтожаемо, цельно, однородно, спокойно и бесконечно. Для него нет ни прошедшего, ни будущего, ибо оно во всей своей полноте живет в настоящем, единое, нераздельное» ${ }^{3}$. Формулює закон тотожності в онтологічному вигляді: «бытие есть, а небытия нет»; «нельзя выделить из бытия бытие, которое согласно мировому порядку <..> не может ни разойтись, ни соединиться» ${ }^{4}$; «Нераздельно же бытие потому, что бытие тесно примыкает к бытию» ${ }^{5}$.

\footnotetext{
${ }^{2}$ Таннери П. Первые шаги древнегреческой науки. Пер. Н. Полыновой и др. Предисл. А. Введенского. Санкт-Петербург, 1902. С. 71.

${ }^{3}$ Таннери П. Первые шаги древнегреческой науки. Пер. Н. Полыновой и др. Предисл. А. Введенского. Санкт-Петербург, 1902. С. 72.

${ }^{4}$ Таннери П. Первые шаги древнегреческой науки. Пер. Н. Полыновой и др. Предисл. А. Введенского. Санкт-Петербург, 1902. С. 71.

${ }^{5}$ Таннери П. Первые шаги древнегреческой науки. Пер. Н. Полыновой и др. Предисл. А. Введенского. Санкт-Петербург, 1902. С. 73.
} 
Гносеологічно ототожнює буття 3 мовою та мисленням: «Мыслить и быть - одно и то же. Слово и мысль должны быть бытием, ибо бытие есть, а небытия нет» ${ }^{6}$. «Одно и то же мысль и предмет мысли, ибо без бытия, в котором выражена мысль, ты не найдешь мысли» ${ }^{7}$. У парадоксальності міститься початковість думки, яка, відхиляючись та вистрибуючи за межі докси, вступає у суперечність із порядком, освяченим традицією та авторитетом доксального права. Проте чи не є це відхилення думки від докси (норми) чимось незаконним? Як випливає з поеми, на шлях пізнання Істини філософа привели Закон (грец. themis) і Правда (грец. dike), тобто шлях до істини для Парменіда пролягає через царину права. Тому i проходження воріт, «через которые пролегают пути Дня и Ночи» ${ }^{8}$, потребує юридичної санкції, яка до того ж є санкцією традиційного, тобто міфологічного права. Законодавча Феміда та Діке, що карає, - персонажі давньої міфології. На відміну від них, Алетейа - новоявлена богиня, а сутнісно - алегорія, авторитет якої ще необхідно буде довести. Згідно 3 античними уявленнями, «алетейа» - об'єктивна істина, правда, справедливість. У соціальному чи суб'єктивному плані ця Істина реалізується як власне закон або звичай (грец. themis) і як те, яким чином цей закон звичайно чи судовим порядком виконується (грец. dike). Та обставина, що саме Феміда та Діке оголошені охоронцями та провідниками в царство Істини, свідчить про те, що сюжет вступної частини варто розуміти як передання божественних повноважень від давніх богинь до нової володарки умів. Алетейа, прихована за грандіозними воротами, має з'явитися в усій своїй відкритості, щоби затьмарити інститути давнього священного права, вирвати це право 3 непередбачуваної та завжди прихованої (захмарної) волі богів. Отже, законодавчою силою має стати сама Істина. Оскільки Істина «здана під ключ», вона має стати ключем до справедливості (істини права). Відмикання подвійного замка в поемі символізує право на «безумство» начального мислення. Це право надається не кожному, а лише тому, хто його «заслужив». Ініціація (оскільки ми говоримо про ініціацію мислення) у прямому розумінні є обрядом, смисл якого полягає в переході від одного статусу в інший, тобто входження до повноти прав зрілої людини. Той, хто ще вчора був юнаком, ставав «мужем, який пізнав», i водночас повноправним членом суспільства: «С нежною речью обратились к ней

\footnotetext{
${ }^{6}$ Таннери П. Первые шаги древнегреческой науки. Пер. Н. Полыновой и др. Предисл. А. Введенского. Санкт-Петербург, 1902. С. 72.

${ }^{7}$ Таннери П. Первые шаги древнегреческой науки. Пер. Н. Полыновой и др. Предисл. А. Введенского. Санкт-Петербург, 1902. С. 73.

${ }^{8}$ Таннери П. Первые шаги древнегреческой науки. Пер. Н. Полыновой и др. Предисл. А. Введенского. Санкт-Петербург, 1902. С. 70.
} 
девы и разумным словом убедили ее снять для них, не медля, окованный железом засов, замыкающий ворота. И вот, раскрыв зияющее жерло, распахнулись двери <..> ${ }^{9}$. За цими дверима перед нами постає глибоченне провалля, пустий простір метафізичного мислення, який має бути засвоєний грецькими філософами шляхом побудови концептуальних зв'язків і заповнення філософськими поняттями та категоріями. Проте родимі плями юридичної спадковості залишаються ще тривалий час. Культурний грецький словник містить яскраво виражену юридичну спадкоємність. Наприклад, слово «категорія» (грец. kategoria «висловлювання, обвинувачення, ознака», від kategoreo - «присуджую, обвинувачую»), до того як стати основним терміном метафізики, мало юридичне значення обвинувачення, присуду. В українській мові такі терміни, як «судження», «присуд», «присудження», мають референцію до суду, судочинства. А такий лінгвістичний термін, як «присудок», що сьогодні позначає один із головних членів речення (порівняймо 3 російським «сказуемое»), постав із судоговоріння. Сама філософія зароджувалася в атмосфері судового процесу на грецькій агорі й удосконалювалася в практиках полісного судоговоріння (грец. kategoria). Вона розверталася не тільки як теорія (видовище самого видовища), але й як «суд розуму». Закон - спільне слово для філософії, науки, юриспруденції. На відміну від єгипетської науки, що існувала в режимі авторитарної (міфологічної) влади, грецька філософія та наука набули особливого аподиктичного стилю. Доказ i спростування як форми обгрунтування істини створювалися в парадигмі неупередженого цивільного судочинства. Насамперед це характерне для афінської школи філософії, становлення якої безпосереднім чином пов'язано 3 темою правосуддя та іï квінтесенцією - судом над самою філософією в особі Сократа.

Отже, поняття істини - значно пізніший феномен. ніж справедливість та iii історично рання форма - правда (право). Закон історично та логічно передує істині, саме тому істина, емансипована зі сфери права, може стати законом, щоб на наступній стадії стати справедливістю - свого роду істиною права. Саме тому питання про справедливість стає головним змістовним питанням Платона, тоді як питання про істину - лише інструментом для його розв'язання.

Геракліт Ефеський (544-483 рр. до н. е.) увів термін «логос» (грец. logos), основні значення якого грецькою: «мовлення», «слово», «закон», «поняття», «смисл». Вважається засновником діалектичного методу.

\footnotetext{
${ }^{9}$ Таннери П. Первые шаги древнегреческой науки. Пер. Н. Полыновой и др. Предисл. А. Введенского. Санкт-Петербург, 1902. С. 70.
} 
Геракліт уперше в історії філософії намагався побудувати відносно завершену теорію пізнання. Вперше ввів у філософію поняття закону та спробував встановити, що являє собою мислення в поняттях. Він провів межу, хоча не дуже чітку, між моментами суб'єктивності й об'єктивності мислення: «Разум общ, но большинство людей живет так, как будто обладают своим особым разумом» ${ }^{10}$. Геракліт висунув проблему відображення руху в мисленні. У нього ми знаходимо опис мислення як такого пізнання, що спирається на поняття (закон) та якому доступним є пізнання загального. Вчення Геракліта - це перший свідомий перехід від чуттєвого світоспоглядання до понятійно-категоріального сприйняття світу. «Необходимый шаг вперед, сделанный Гераклитом, заключается в том, что он перешел от бытия как первой непосредственной мысли к становлению как второй мысли» ${ }^{11}$.

\section{2. Від логосу до епістеми}

У процесі раціоналізації знання в Давній Греції місце антропоморфних богів, що уособлювали природні й інші сили, посідають абстрактні поняття. Потреба пізнати світ (істину) шляхом мислення з понять (logos), а не 3 відчуттів, зумовлена насамперед роздумами логічного характеру. Давньогрецькою філософською школою, яка вперше розрізнила мислення (i мислиме буття) та чуттєві дані (і буття, що сприймається чуттєво), виділила буття як поняття про реальність, була Елейська школа (Ксенофан, Парменід, Зенон Елейський, Мелісс Самоський, Горгій). Завдяки цьому вперше здійснений поділ між поняттям і тим, що воно позначає, поняття стає окремим предметом дослідження. Буття дане тільки в думці, думка ж $\epsilon$ виключно як думка про буття, у цьому вони тотожні. Для Парменіда немає буття, яке не було б свідомістю, не було б мислимим. Онтологія філософа являє собою форму свідомого раціоналізму, що виключає будьякий чуттєвий досвід і навіть заперечує його зміст. Для елейців у цьому світі, в абстрактному бутті цілком збыгаються речовинність та духовність. Оскільки останні ще не мисляться як різні форми дійсності, цю філософську систему не можна назвати ні матеріалістичною, ні ідеалістичною в сучасному розумінні.

Учень Парменіда Зенон Елейський (490-430 рр. до н. е.) стихійно підійшов до питання про суперечливість явищ природи та вираження цієї суперечливості в поняттях. Він намагається розкрити суперечності, що полягають у повсякденній гадці про множинність та змінюваність речей, за

\footnotetext{
10 Таннери П. Первые шаги древнегреческой науки. Пер. Н. Полыновой и др. Предисл. А. Введенского. Санкт-Петербург, 1902. С. 188.

${ }^{11}$ Гегель Г.В.Ф. Лекции по истории философии: в 3-х книгах. Т. 1. Санкт-Петербург : Наука, 1993. C. 287.
} 
допомогою логічних аргументів. Зенон серед перших наблизився до розуміння формально-логічних відношень, і вже Аристотель називав його винахідником діалектики та зазначав, що він першим почав вчити мистецтву спростовувати думку опонента, навичкам усної бесіди, діалогу. У ньому якнайбільше мали потребу правники та їхні клієнти, державні мужі й простолюдини. Діалектика Зенона - специфічний метод міркування, за допомогою якого намагаються виявити суперечності в доводах опонентів. Зі своєї тези про існування буття та неіснування небуття Парменід дійшов висновку про незрушність та єдиність буття, відповідно, неіснування руху та множинності як таких. Опоненти Парменіда вважали зазначені висновки абсурдними. Зенон намагався довести, що аргументи опонентів Парменіда ще більш абсурдні, ніж тези, що ними критикуються. Свої спростування спростувань він побудував у формі логічних парадоксів-апорій (грец. aporia - «безвихідь»). Апорії Зенона показали своєрідність чуттєвого та раціонального ступенів пізнання: нехтування своєрідністю чуттєвого і раціонального етапів пізнання призводить до визнання з необхідністю очевидного неочевидним.

Доелейське мислення в основному було чуттєвим, оскільки думка філософів-натуралістів не була здатна набути абстрактно-логічної форми, тобто відмежуватися від чуттєвого сприйняття навколишнього світу. Звільнивши думку від чуттєвого сприйняття шляхом відкриття іiї логічних властивостей, елейці не змогли застосувати їх для опису речей, що сприймаються чуттєво, без породження суперечностей. До них оголошували та віщували, просили та вимагали, вони ж почали аргументувати.

Емпедокл Акрагантський (прибл. 490-430 pр. до н. е.) - давньогрецький філософ, який не належав до конкретної школи, творець однісї з перших наукових програм: його вчення є своєрідною сходинкою на шляху від міфу до логосу. За повідомленням Феофраста, Емпедокл був прихильником Парменіда та наслідував останнього у своїх творах. За свідченням Алкідама, Емпедокл слухав Парменіда одночасно із Зеноном. Отже, зовсім не випадково, що філософія Емпедокла в основній своїй частині була спрямована на розв'язання завдання, поставленого поемою Парменіда «Про природу» щодо протистояння двох непримиримих частин: Гадки «докси» (грец. doxa) й Істини «алетейї» (грец. aletheia), остання 3 яких принципово відмовлялася пояснити явища емпіричного світу. Якщо Зенон був вірним учнем Парменідової «Істини», то Емпедокл став завзятим послідовником його «Гадки». Він виступає проти «Істини» Парменіда в ім'я емпіричного знання. Досконале знання Емпедокл вважає недосяжним через неминучу для кожної людини неповноту знання, що зумовлена 
швидкоплинністю людського життя, обмеженістю тілесної організації та моральною недосконалістю. На початку своєї поеми «Про природу» Емпедокл звертається до свого учня Павсанія 3 напутньою порадою: «Внимай же моим словам, ибо наука [«епістема» (грец. episteme) $-K$. Д.] увеличивает разум. Как я раньше сказал, указав границы своей речи, она будет двояка: то единое возрастало из многого, чтобы быть одним; то наоборот, оно распадалось, чтобы было многое из одного $<. .>\ll^{12}$, зазначає: «Узки средства познания, разлитые по телу, и множество возникающих страданий смущает заботами ум; видев только малую часть несчастной жизни, они, быстро умирающие, рассеваются подобно легкому дыму, веря каждый лишь в то, что сам повстречал. Влекомый во все стороны, всякий сам желает постичь всю вселенную; но люди не могут ни видеть ее, ни слышать, ни даже схватить разумом. Ты же, пришедший сюда, ты узнаешь не больше, чем сколько видит мысль смертного» ${ }^{13}$. Після звернення до богів, наслідуючи Парменіда, філософ також звертається до музи, плодом одкровення якої $є$ істинне знання: «Вы же, о боги, отвратите безумие (этих?) [тих, хто заперечує значення відчуттів для пізнання, наприклад, Парменід у ч. 1 поеми - $K$. Д.] от моего языка, пусть из священных уст течет чистый источник. А тебя, памятливая муза, белорукая дева, умоляю, дозволь слушать, на сколько возможно существам эфемерным; пошли, руководимая благочестием, быструю колесницу. Меня не вынудят изысканной почести цветы, которые я мог бы получить у смертных, сказать более, чем дозволено» ${ }^{14}$. Метод, що пропонується мислителем, - не нехтувати жодним із можливих джерел пізнання: «Дерзни же и воспрянь к вершинам мудрости. Исследуй всеми силами все, что в предмете ясно, но не думай видеть больше, чем доступно глазу, не слышать тупым слухом более того, что отчетливо высказано, не доверяй и другим, каким ни есть, путям знания; не давай веры ощущениям и размышляй, как все себя выясняет» ${ }^{15}$. У теорії пізнання Емпедокла наявний принцип уподібнення. У зв'язку із цим мислення тісно пов'язане й уподібнене тілу, а також аналогічне відчуттю. Оскільки ж відчуття визначається змішуванням елементів, тому краще за все виражене кров’ю, то розуміння «питается в бурных волнах крови, и отсюда происходит подвижная мысль человека,

\footnotetext{
12 Таннери П. Первые шаги древнегреческой науки. Пер. Н. Полыновой и др. Предисл. А. Введенского. Санкт-Петербург, 1902. С. 90.

13 Таннери П. Первые шаги древнегреческой науки. Пер. Н. Полыновой и др. Предисл. А. Введенского. Санкт-Петербург, 1902. С. 88.

14 Таннери П. Первые шаги древнегреческой науки. Пер. Н. Полыновой и др. Предисл. А. Введенского. Санкт-Петербург, 1902. С. 89.

15 Таннери П. Первые шаги древнегреческой науки. Пер. Н. Полыновой и др. Предисл. А. Введенского. Санкт-Петербург, 1902. С. 89.
} 
потому что мысль в людях - это кровь, омывающая сердце» ${ }^{16}$. Для філософа той, хто пізнає, і те, що пізнається, мають спільний склад і тому можуть взаємодіяти: «Ибо человеческий разум растет соответственно представляющемуся. Насколько изменяются люди, настолько всегда и разум им представляет иные мысли. При посредстве земли мы видим землю, при посредстве воды - воду, посредством эфира - божественный эфир, через огонь - разрушительный огонь, любовью - любовь, и ненавистью - печальную ненависть: потому что ими соединены гармонично все вещи, ими [люди] думают, радуются или страдают» ${ }^{17}$. В ученні Емпедокла діє методологічний принцип спільної заповнюваності: « ..> везде есть мысль и доля необходимости $<\ldots>$ « ${ }^{18}$. Прийняття знання як головної підстави світогляду та діяльності людини є характерним для моністично орієнтованої свідомості. За своєю суттю знання виключає онтологічну варіативність, стверджуючи повторення завжди наявного закону (порядку). Для Емпедокла відчуття, думка, а також усе пізнання в певному розумінні зводяться до взаємодії фізичних тіл. Завдяки цій взаємодії люди здобувають знання про світ, оскільки вони складаються 3 тих самих елементів, що й світ, і там, де вказані елементи змішані в подібних пропорціях, виникають свідомість та обізнаність. Отже, знання залежить від фізичного стану, який впливає на наші взаємовідносини із зовнішнім світом. Усе у світі природи є тільки тимчасовим сполученням елементів, що виникло в результаті боротьби між двома силами, одна 3 яких прагне єдності, а інша намагається досягти розділення. Так дається фізичне обгрунтування віри в спорідненості всього, що існує, яка пронизує всю наукову думку Емпедокла.

Усвідомлюючи безвихідність ситуації, що склалася в пізнанні, Емпедокл у поемі «Очищення» зазначає: «Друзья, я знаю, что истина в словах, которые я произнесу; но тяжело людям и ненавистно внедрение веры в умы» 19 . Філософ у поемі «Про природу» звертає увагу на те, що суперечності між сущим та явищами, що лише здаються, зумовлене також мовою пізнання, наявною як у процесі пізнання, так і у фіксуванні його результатів. Мислитель на прикладі вживання слів «народження» та «смерть» показує, що неправильне вживання слів, тобто не відповідно до їхнього справжнього значення, спроби відобразити за допомогою мови

\footnotetext{
16 Таннери П. Первые шаги древнегреческой науки. Пер. Н. Полыновой и др. Предисл. А. Введенского. Санкт-Петербург, 1902. С. 101.

17 Таннери П. Первые шаги древнегреческой науки. Пер. Н. Полыновой и др. Предисл. А. Введенского. Санкт-Петербург, 1902. С. 101-102.

18 Таннери П. Первые шаги древнегреческой науки. Пер. Н. Полыновой и др. Предисл. А. Введенского. Санкт-Петербург, 1902. С. 98.

19 Таннери П. Первые шаги древнегреческой науки. Пер. Н. Полыновой и др. Предисл. А. Введенского. Санкт-Петербург, 1902. С. 103.
} 
«того, чого немає, як те, що є», спрямовують мислення на хибний шлях, який веде не до істини, а до омани: «Ты же, как то велят правдивые наставления нашей музы, познай, сделав в уме разумное деление. Про всякое существо, происшедшее, подобно человеку, смешением появившегося на свет эфира, или наподобие дикого зверя, или же дерева, или птицы, - говорят, что оно родилось; когда они [части] разлагаются, это напротив, нелепо называют смертью, и я буду следовать обычаю» ${ }^{20}$. Емпедокла влаштовує звичайне слововживання, але лише після усунення обману, що викривляє предмети, після повернення іменам їхнього звичайного значення. Хоча Емпедокл не усвідомлював необхідності створення спеціальної мови науки та їі категоріально-понятійного апарату, він був першим із давньогрецьких філософів, хто висунув спеціальні вимоги до мови пізнання.

\section{3. Від законів природи до законів людських}

У середині V ст. до н. е. інтереси давньогрецьких філософів змістилися від космосу і природи до дослідження людини як частини суспільства, іiі внутрішнього світу та розуму. Давні греки високо ставили людський розум. Софокл (прибл. 496-406 рр. до н. е.) у трагедії «Антігона», створеної 441 р. до н. е., зазначає: «Дивних багато у світі див, найдивніше iз них - людина < ..> i мислей, як вітер швидких, і мови навчивсь чоловік, звичаїв громадських пильнує здавна $<\ldots>\ll^{21} ; \ll<\ldots>$ розум, що боги дарують нам, то скарб найвищий i дорожчий всіх скарбів $<\ldots>$ « $^{22}$. У зазначеному творі також відображений спір між прихильниками традиційних звичаїв - «неписаного права» (грец. agrafos nomos) i прихильниками державного права - «писаного права» (грец. nomos gegramenos). Але вже у 20-х pp. V ст. до н. е. суперечності між «писаним» і «неписаним правом» поступилися місцем новим - між «природою» (грец. physis) і «законом» (грец. nomos). «Неписані» закони стали визначатися як «природні» i протиставлятися законам, установленим людьми, тобто мінливим. 3'являється поняття «природного» права. 3 іншого боку, виникає віра в людські установлення й угоди (грец. thesis), людські знання (грец. episteme), що спроможні змінювати закони та державний устрій. Характерною ознакою вказаних спорів був абстрактний характер уживаної термінології. У зв'язку з речовинним розумінням чуттєво-матеріального

20 Таннери П. Первые шаги древнегреческой науки. Пер. Н. Полыновой и др. Предисл. А. Введенского. Санкт-Петербург, 1902. С. 91.

${ }^{21}$ Софокл. Трагедії. Перекл. 3 давньогр. А. Содомори та Бориса Тена. Передм. А. Білецького. Київ : Дніпро, 1989. С. 137.

${ }^{22}$ Софокл. Трагедії. Перекл. 3 давньогр. А. Содомори та Бориса Тена. Передм. А. Білецького. Київ : Дніпро, 1989. С. 148. 
космосу мова в Давній Греції визначалася як сукупність імен речей. Давньогрецькі філософи розмірковували про походження імен, оскільки прагнення до пошуку «першопочатку», що пронизувало ранню давньогрецьку філософію, привело до спроб вирішити цю важливу проблему. Атомісти Левкіпп (прибл. 500-440 рр. до н. е.) і Демокріт Абдерський (прибл. 460-370 pр. до н. е.) не задовольнялися лише описом природи під час іiї дослідженнія, а шукали причинного пояснення явищ. За свідченням Аеція, Левкіпп у творі «Про розум» зазначав: «Ни одна вещь не возникает беспричинно, но все возникает на каком-нибудь основании и в силу необходимости» ${ }^{23}$. Секст Емпірик вказує, що Демокріт виділяв такі критерії істини: «<..> 1) критерий постигания того, что скрыто, этот критерий касается мира чувственных явлений; 2) критерий научного исследования, он относится к размышлению <...; 3) критерий выбора и бегства, он принадлежит области чувств; дело в том, что то, к чему мы стремимся приблизиться, желательно для нас, а того, от чего мы стремимся удалиться, мы хотим избегнуть» ${ }^{24}$. Філософ розрізняв два види пізнання: чуттєве, яке він називав «темним» (грец. gnome skotie), знайомить нас лише 3 видимістю речей, та розумне, яке він називав «світлим» (грец. gnome gnesie), глибше проникає в сутність речей. В основу співвідношення та розрізнення Демокрітом природної справедливості (природного права) й полісного закону (позитивного права) покладено розрізнення ним двох видів пізнання і двох видів існування речей та явищ. Згідно зі Стобеєм, Демокріт вважав, що: «Закон хочет хорошо устроить жизнь людей. Сможет же он сделать это лишь в том случае, если сами люди хотят, чтобы им было хорошо. Ибо закон обнаруживает свое благотворное действие лишь тем, кто ему повинуется» ${ }^{25}$.

Також дуже важливим для давньогрецьких мислителів було питання про «правильність імен» (взаємовідношення між речами, думками і словами). Ними запропоновано два підходи для вирішення проблеми характеру зв'язку між іменами та позначуваними ними предметами, що відображені в діалозі Платона «Кратіл». Так, один з учасників діалогу Кратіл вважає, що: «<..> существует правильность имен, присущая каждой вещи от природы, и вовсе не та, произносимая вслух частица нашей речи, которой некоторые из нас договорились называть каждую вещь, есть имя, но определенная правильность имен, прирожденная эллинам, и варварам, всем одна и та же» ${ }^{26}$. Інший учасник діалогу Гермоген дотримується протилежної думки:

\footnotetext{
${ }^{23}$ Маковельский А. Древнегреческие атомисты. Баку : НКП Азербайджанской ССР, 1946. С. 208.

${ }^{24}$ Маковельский А. Древнегреческие атомисты. Баку : НКП Азербайджанской ССР, 1946. С. 241.

${ }_{25}^{25}$ Маковельский А. Древнегреческие атомисты. Баку : НКП Азербайджанской ССР, 1946. С. 320.

${ }^{26}$ Платон. Собрание сочинений: в 4 т. Т. І. / под общ. ред. А. Лосева и др.; авт. вступит, статьи А. Лосев; примеч. А. Тахо-Годи. Пер. с древнегреч. Москва : Мысль, 1990. С. 613.
} 
«<..> правильность имени есть что-то другое, нежели договор и соглашение. <..> Ни одно имя никому не врождено от природы, оно зависит от закона и обычая тех, кто привык что-либо так называть» ${ }^{27}$. Відповідно до повідомлення Прокла 3 коментаря до діалогу Платона «Кратіл», «Демокрит, утверждая, что имена от установления, обосновывал это четырьмя умозаключениями. От равноименности: различающиеся между собою вещи называются одним именем; стало быть, имя не от природы. Затем, от многоименности: если различающиеся между собою имена подходят к одной и той же вещи, то, стало быть, они подходят и друг другу, а это невозможно. Третье - от перемены имени: ибо на каком основании мы переименовали бы Аристокла в Платона, а Тиртама в Теофраста, если бы имена были от природы? Затем - от недостатка в

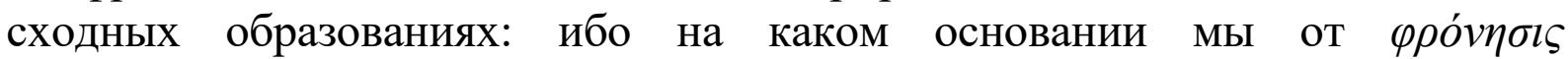

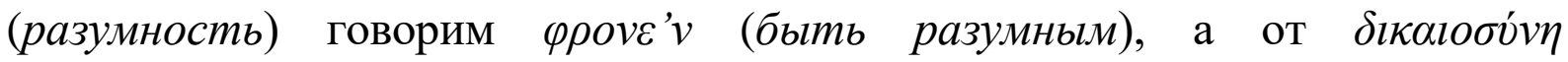
(справедливость) уже не образуем такого производного? Стало быть, имена от случая, а не от природы. И сам он называет первое умозаключение многозначностью, второе - равновесием, третье - переименованием, четвертое - безымянностью» ${ }^{28}$. Софісти вважали, що оскільки імена, створюючи предмети ілюзорного чуттєвого світу, не мають реального буття, випадають із нього, то вони розглядаються «как человеческое установление, допускающее изменения» ${ }^{29}$. Ідея про суб'єктивний характер знання, зумовлений внутрішнім станом людини та іiі ставленням до навколишнього світу, була сформульована софістами. На відміну від Геракліта Ефеського (544-483 рр. до н. е.) та Парменіда Елейського (540480 рр. до н. е.), які говорили про об'єктивність істини, про істотну відмінність істинного знання від гадки ${ }^{30}$, софісти стверджували, що не може бути нічого істинного та справедливого незалежно від людини та суспільства. Саме в цей час формулюється протиставлення «природа» «закон», щодо якого I. Троцький зазначав: «По поводу всех социальных отношений, даже шире, по поводу всех содержаний сознания ставится вопрос: существуют ли они по «природе» как неотъемлемые свойства объектов в смысле прежнего мифологического миросозерцания, или по

27 Платон. Собрание сочинений: в 4 т. Т. І. / под общ. ред. А. Лосева и др.; авт. вступит, статьи А. Лосев; примеч. А. Тахо-Годи. Пер. с древнегреч. Москва : Мысль, 1990. С. 614.

28 Античные теории языка и стиля / под общей ред. О. Фрейденберг. Москва ; Ленинград : ОГИЗ ; СОЦЭКГИЗ, 1936. С. 32-33.

29 Античные теории языка и стиля / под общей ред. О. Фрейденберг. Москва ; Ленинград : ОГИЗ ; СОЦЭКГИЗ, 1936. С. 14.

${ }^{30}$ Кучеренко Д. Понятійно-правове мислення у Давній Греції: від міфу до логосу. International Multidisciplinary Conference "Key Issues of Education and Sciences: Development Prospects for Ukraine and Poland", Stalowa Wola, Republic of Poland, 20-21 July 2018. Volume 2. Stalowa Wola : Izdevnieciba "Baltija Publishing", 2018. P. 18-19. 
«закону», как человеческие мнения и результат соглашения между людьми?» ${ }^{31}$. У розумінні софістів про речі, що залучені в загальний процес руху та змін, не можна сказати нічого конкретного, тому що скільки людей, стільки поглядів й істин; на все необхідно дивитися з особистого погляду. Наприклад, Гермоген (V-IV ст. ст. до н. е.) стверджував, що є тільки гадка і гадка кожного - iстина $^{32}$. Продік Кеоський (прибл. 465-395 рр. до н. е.) увів поняття байдужості речей, які набувають цінності виключно за правильного їх використання, що приписується розумом: «<..> каковы те, которые ими пользуются, таковы по необходимости у них и вещи» ${ }^{33}$. Горгій Леонтінський (483-375 рр. до н. е.) у творі «Про природу, або про неіснуюче» вказував на непізнаваність речей: «<..> ничто не существует; $<\ldots>$ если (что-либо) и существует, то оно непознаваемо для человека; > . .> если оно и познаваемо, то все же, по крайней мере, оно непередаваемо и необъяснимо для ближнего» ${ }^{34}$. Він говорив про неможливість єдиного розуміння будь-якого предмета різними людьми, які перебувають у різних умовах. Горгій вважав, що виражений певним терміном єдиний предмет, що являв собою єдиний зміст думки, у процесі його сприйняття людьми розпадається на численні змісти думки та втрачає свою єдність. 3 такого погляду предмет не буде тотожний собі також і для однісї людини, тому що в різний час і в різних умовах іiі можливості та спроможності сприйняття будуть різними. Горгій конструює подвійний образ закону: природному закону як об'єктивному порядку речей відповідають писані закони як людські винаходи, «охоронці справедливості». Він зазначав, що будь-які людські установлення - штучні («писані закони»), тому умовні ${ }^{35}$. Протагор Абдерський (прибл. 481-411 рр. до н. е.), назвавши людину мірою всіх речей, обмежив знання про навколишній світ межами відчуттів, переживань, гадок. Цей основоположний принцип софістів розходився із загальновизнаними на той час поглядами про первинність саме божественного (природного), а не людського начала як критерію оцінки всіх явищ навколишнього світу. За свідченнями Діогена Лаертського, «Он первый заявил, что о всяком предмете можно сказать двояко и противоположным образом, и сам первый стал пользоваться в спорах доводами. < ..> Он первый стал брать за уроки плату в сто мин; первый стал различать времена глагола и точно выражать время действия; стал

\footnotetext{
31 Античные теории языка и стиля / под общей ред. О. Фрейденберг. Москва ; Ленинград : ОГИЗ ; СОЦЭКГИЗ, 1936. С. 14.

${ }^{32}$ Платон. Собрание сочинений: в 4 т. Т. І. / под общ. ред. А. Лосева и др.; авт. вступит, статьи А. Лосев; примеч. А. Тахо-Годи. Пер. с древнегреч. Москва : Мысль, 1990. С. 614-616.

${ }_{33}$ Маковельский А. Софисты. Вып. 2. Баку : НКП Азербайджанской ССР, 1941. С. 16.

${ }^{34}$ Маковельский А. Софисты. Вып. 1. Баку : НКП Азербайджанской ССР, 1940. С. 30.

${ }^{35}$ История правовых и политических учений : учебник для вузов / под общ. ред. В. Нерсесянца. 4 изд., перераб. и доп. Москва : Норма, 2004. С. 51.
} 
устраивать состязания в споре и придумал уловки для тяжущихся; о мысли он не заботился, спорил о словах, и повсеместное нынешнее племя спорщиков берет свое начало от него» ${ }^{36}$. Він вчив, що відчуття права та совість - загальний дар богів, подарований усім людям. Прагнення до раціональності спонукало Протагора винести на суд розуму як творіння права, так і творіння мови. Антифонт Афінський (прибл. 480-411 рр. до н. е.), якого можна назвати першим номіналістом, написав твір, що складається із двох книг, під назвою «Істина». У першій книзі, що стосувалася загальних питань метафізики і теорії пізнання, представлена полеміка проти опредмечування (гіпостазування) понять: «<..> познающий некие длинные предметы не может видеть длину глазами, ни познавать ее духом» ${ }^{37}$. Така мова, що виражала абстракції іменниками, нібито уподібнюючи їх речам, готувала шлях наївному реалізму у філософському сенсі. Антифонт писав: «Для разума все есть единое. Поняв это, ты будешь знать, что для него, разума, [не существует] ничего единичного; ничто из того, что видят глазами, насколько может простираться зрение [человека], и из того, что опознают мыслью, насколько может простираться познание [человека], не единично» ${ }^{38}$. Зазначав, що «<..> многие предписания, признаваемые справедливыми по закону, враждебны природе (человека). $<. .>$ Что же касается полезных (вещей), то те из них, которые установлены (в качестве полезных) законами, суть оковы (для человеческой) природы, те же, которые определены природой, приносят (человеку) свободу» ${ }^{39}$. Продовжуючи ідею Протагора про загальну рівність усіх людей від природи, Антифонт виходив із того, що всі люди мають однакові природні потреби. Нерівність людей, на його думку, походить не із природи, а 3 людських законів. Антифонт, на відміну від Горгія, констатує розходження між людським законом і природним станом речей: від природи всі люди $є$ рівними, проте законами створюються переваги та відмінності. У творі «Про однодумство» Антифонт писав, що серед громадян має бути однодумство в розумінні закону ${ }^{40}$. Він радикалізує антитезу «природи» (грец. physis) і «закону» (грец. nomos), стверджуючи в термінах елейців, що природа - це істина, а позитивне право - гадка, що одне майже завжди є антитетичним іншому. Необхідно, як вважає Антифонт, дотримуватися природного закону, навіть у порушення людського, якщо це є необхідним i

\footnotetext{
36 Диоген Лаэртский. О жизни, учениях и изречениях знаменитых философов / ред. тома и авт. вступ. ст. А. Лосев. Перевод М. Гаспарова. 2 изд. Москва : Мысль, 1986. С. 348-349.

${ }^{37}$ Гомперц Теодор. Греческие мыслители. Т. 1 / науч. ред., коммент. и предисл. А. Цыба. Пер. с нем. Д. Жуковского, Е. Герцык. Санкт-Петербург : Алетейя, 1999. С. 408.

${ }_{38}^{38}$ Маковельский А. Софисты. Вып. 2. Баку : НКП Азербайджанской ССР, 1941. С. 37.

${ }^{39}$ Маковельский А. Софисты. Вып. 2. Баку : НКП Азербайджанской ССР, 1941. С. 44.

${ }^{40}$ Маковельский А. Софисты. Вып. 2. Баку : НКП Азербайджанской ССР, 1941. С. 48.
} 
не загрожує покаранням. У зв'язку із введенням софістами дихотомії природних i людських законів писане право ставало предметом нескінченних сумнівів, критики та перевірки. Виходячи 3 того, що все незмінне є фікцією, софісти дійшли висновку, що загальні визначення та поняття є фіктивними (суб'єктивна гнучкість понять). Вони оголосили, що пошук «істини взагалі», «справедливості взагалі» та будь-чого «взагалі» $\epsilon$ марним. Безглуздо припускати існування умоглядної істини: абстрактної істини немає, істина завжди конкретна, оскільки вона індивідуальна. Теорія пізнання софістів прямо вела до відносності індивідуальної гадки. Софісти стояли на порозі корінного повороту у філософії, перейшовши від натурфілософських питань про устрій світу до питань про улаштування людини в суспільстві та державі. Вони звернулися до дослідження людського мислення та його засобу - слова, мови 3 метою зафіксувати відсутність будь-яких правил мислення й об'єктивної детермінації i мислення, і мови. У софістів мислення та мовлення зливаються, тобто філософсько-логічний аспект зливається 3 лінгвістичним, а місце зароджуваної в досократиків логіки (діалектики) посідають риторика, граматика, семантика, синтаксис. Аналіз смислу логічних категорій поступається місцем аналізу значень слів як у Давній Греції, так і в наш час.

\section{ВИСНОВКИ}

Встановлено, що розвиток давньогрецького понятійного мислення, понятійно-правового мислення також, пройшов декілька етапів: від міфу до логосу, від логосу до епістеми, від законів природи до законів людських. Водночас у давніх греків понятійно-правове мислення не було відокремлено від загального понятійного мислення. На міфологічній стадії розвитку відбулося усвідомлене розрізнення людиною свого внутрішнього світу із зовнішнім світом, сформувалася здатність людини до узагальнення чуттєвих даних. Це стимулювало накопичення й узагальнення наочночуттєвого матеріалу, в якому переплітаються емоційно-художні та раціональні моменти. Оформлення міфологічного типу пізнання надало можливість людині вийти за межі безпосередньо-чуттєвої, наочної дійсності, наблизило міфологічну традицію до появи філософського способу мислення, до натурфілософської стадії свідомості та пізнання. Ця перша стадія розвитку понятійної здатності свідомості з'являється в результаті відокремлення розумової діяльності людини від іiі безпосередньо практичної діяльності. Пошук справедливості відбувався за допомогою універсального критерію, яким визнавалася «істина» на відміну від буденної та мінливої гадки. Відокремлення мислення від чуттєвого сприйняття світу привело до вироблення абстрактного понятійного 
міркування, поділу між поняттям і тим, що воно позначає. Давньогрецька культура, розвиваючись шляхом раціоналізації знання, замість авторитета традиції (звичаєве право) поставила авторитет закону, замість релігійного авторитета - авторитет людини та ¥ї розуму. Проте виявилося, що мислення поняттями не завжди приводить до однозначних та істинних висновків. Було встановлено, що правильність міркувань та їхній результат залежать також і від мови пізнання, від слів, які вживаються.

\section{АНОТАЦІЯ}

Розглядається історія виникнення та розвитку понятійно-правового мислення в Давній Греції. Досліджується перехід від міфологічної (допонятійна) стадії через філософську до наукової (понятійна) стадії мислення. Зародження філософії в Європі полягало у відмові, на рівні свідомої думки, від міфологічних вирішень проблем, пов'язаних iз походженням і природою всесвіту та процесів, що відбуваються усередині нього. На рівні свідомості ранньогрецькі філософи відкидали міфологію, але спорідненість із нею зберігалася через «імпліцитне прийняття міфологічних понять». У грецькому світі був утворений особливий відтінок мислення, що відрізнявся і від повних глибокого символізму міфів, і від розбору конкретних прикладів - було розроблене абстрактне оперування поняттями. Тобто саме давньогрецька думка відкрила мислення в поняттях як таке, стала родоначальником понятійного мислення. Під час дослідження встановлено, що процес понятійноправового мислення в Давній Греції пройшов шлях розвитку від міфопоетичної (абстрактної) форми - через філософську (категоріальну) до наукової (логіко-понятійної) форми у зв'язку з усвідомленням людиною онтологічного (порядок), правового (справедливість) та гносеологічного (істина) смислів.

\section{ЛІТЕРАТУРА}

1. Николаева Л., Поломошнов А. Философия : учебник. Часть 1. История мировой философии. Персиановский : Донской ГАУ, 2017. 266 с.

2. Таннери П. Первые шаги древнегреческой науки. Пер. Н. Полыновой и др. Предисл. А. Введенского. Санкт-Петербург, 1902. 470 с.

3. Гегель Г.В.Ф. Лекции по истории философии: в 3 книгах. Т. 1. СанктПетербург : Наука, 1993. 350 с.

4. Софокл. Трагедії. Перекл. $з$ давньогр. А. Содомори та Бориса Тена. Передм. А. Білецького. Київ : Дніпро, 1989. 303 с.

5. Маковельский А. Древнегреческие атомисты. Баку : НКП Азербайджанской ССР, 1946. 401 с. 
6. Платон. Собрание сочинений: в 4 т. Т. І. / общ. ред. А. Лосева и др.; авт. вступит. статьи А. Лосев; примеч. А. Тахо-Годи. Пер. с древнегреч. Москва : Мысль, 1990. 860 с.

7. Античные теории языка и стиля / под общей редакцией О. Фрейденберг. Москва ; Ленинград : ОГИЗ ; СОЦЭКГИЗ, 1936. 344 с.

8. Кучеренко Д. Понятійно-правове мислення у Давній Греції: від міфу до логосу. International Multidisciplinary Conference "Key Issues of Education and Sciences: Development Prospects for Ukraine and Poland", Stalowa Wola, Republic of Poland, 20-21 July 2018. Volume 2. Stalowa Wola : Izdevnieciba "Baltija Publishing", 2018. 212 p.

9. Маковельский А. Софисты. Вып. 2. Баку : НКП Азербайджанской CСР, $1941.100 \mathrm{c}$.

10. Маковельский А. Софисты. Вып. 1. Баку : НКП Азербайджанской CCP, 1940. $49 \mathrm{c}$.

11. История правовых и политических учений : учебник для вузов / под общ. ред. В. Нерсесянца. 4изд., перераб. и доп. Москва : Норма, 2004. 944 c.

12. Диоген Лаэртский. О жизни, учениях и изречениях знаменитых философов / ред. тома и авт. вступ. ст. А. Лосев. Перевод М. Гаспарова. 2 изд. Москва : Мысль, 1986. 571 с.

13. Гомперц Теодор. Греческие мыслители. Т. 1 / науч. ред., коммент. и предисл. А. Цыба. Пер. с нем. Д. Жуковского, Е. Герцык. Санкт-Петербург : Алетейя, 1999. 606 с.

Information about authors: Kucherenko D. S., Legal counsel "COMREC LTD" 177A, Culturna str., Zaporizhzhia, 69040, Ukraine Hamburh L. S., Candidate of Juridical Sciences (Ph. D. in law sciences), Associate Professor, Assistant Professor of Theory, History of State and Law and International Law Department of Classic Private University 70B, Zhukovsky str., Zaporizhzhia, 69002, Ukraine 